\title{
Water grabbing/ land grabbing in shared water basins the case of Salween River Hatgyi Dam
}

\section{E. Zerrouk}

GSGES, Kyoto University, Japan

Email address:

emelzerrouk@hotmail.com

\section{To cite this article:}

E. Zerrouk. Water Grabbing/ Land Grabbing in Shared Water Basins the Case of Salween River Hatgyi Dam. Journal of Water Resources and Ocean Science. Vol. 2, No. 5, 2013, pp. 68-78. doi: 10.11648/j.wros.20130205.13

\begin{abstract}
Land grabbing by foreign governments and international companies is on the rise. Faced by population growth and an ever-decreasing availability of useable/affordable land in populace states, many are looking to buy land where it is available, predominantly for agricultural and industrial purposes. But land alone is not sufficient for either of these uses. The availability of useable water resources is also a prerequisite to each land purchase. To buy land is to own its green water and have access to any blue water available to it. The development of hydropower projects, however, endeavours to buy the use of blue water, and must also come with a purchase/lease of the surrounding lands. Thus, it can also be seen as a type of 'water grabbing'. Where the locally affected, vulnerable, pre-existing stakeholders are against the project and the loss of livelihood and rights it engenders, a hydropower project may be labelled as a vehicle for water and land grabbing. For an international river, a part of a shared basin, the water grabbing affects stakeholders living under various political regimes and with disparate local power relations. The effects of the project on both sides of a border may be the same; however, the manner in which the two governments handle the effects will be different. The Case of the Hatgyi Dam development on the Salween River, a joint project between China, Myanmar and Thailand, is an example of the above. As a controversial dam being built on an international, border river, the Hatgyi Dam case study exemplifies many of the issues to be found in similar developments across the developing world.
\end{abstract}

Keywords: Hatgyi Dam, Myanmar, Water Grabbing, Land Grabbing

\section{Introduction}

The 2008 economic crisis, and its run-up,led the way to an increase in worldwide land grabbing and water grabbing. States and powerful interest groups, concerned with food and water security, looked at reducing their reliance on the international market to meet their consumptive needs. With limited resources available within their own borders, and high labour costs, they looked to invest in lands elsewhere that could supply their needs, targeting mostly developing countries eager to attract Foreign Direct Investment (FDI). But land/water grabs can exacerbate complex hegemonic relations between states, and within nations and communities, especially asland and water are being reappropriated away from vulnerable stakeholders. The 'sale' of water resources, finite andessential, to investors as part of a development project has far-reaching implications for those formerly reliant on them. In the case of a shared water basin, the political and social dimensions of this sale are further complicated.This paper seeks to explore the concept of water/land grabbing and to apply it to a case study in Myanmar, a least developed country(LDC) that is undergoing a process of rapid investment and reform. The case of the Hatgyi Dam, located in the international Salween River basin, is an example of what can be easily termed 'water grabbing.' Unlike many emerging water grabbing case studies it is concerned with the grabbing of water and land for hydropower development rather than for direct agricultural or industrial purposes. However, an underlying concern for equity and inequality links the Hatgyi Dam case to other land/water grabs occurring within Myanmar and around the globe.

Resource 'grabbing,' land or water, as a concept and not just as an action, names an epistemological framework through which to analyse how control of land and its resources is shifting away from, vulnerable,pre-existing stakeholders $^{1}$ and its negative effects. It is concerned with an increasing rate of land acquisition and land use change. The bias exists in this approach that the re-allocation/use of

${ }^{1}$ Whether human or other biological dependents. 
the land and/or resources is negative, and thus this type of analysis favours subaltern perspectives and risks sidelining larger narratives that may also be present ${ }^{2}$. However, its strength is also in its ability to project the concerns of the 'other' ${ }^{3}$.As a narrative framework ithas the ability to simultaneously de-centralize the human aspect of development and investment, by putting the land and its resources front and centre, while also ensuring that the 'humane' aspects are highlighted, i.e. the treatment of, and effects the changes will have on, the human and the environment from a moral and rights standpoint. Thus, in a decade of rapid re-appropriation of land by powerful interest groups, a trend that is detrimentally effecting the livelihood of many in the 'developing' world, the rhetoric of 'land/water grabbing' is gaining popularity and is becoming a useful way in which to communicate the complexities of these issues.

The recent spike in land and water grabbing came out of the 2008 financial crisis and a perceived food crisis. With rising commodity prices a ripple of unease struck those countries that are almost wholly reliant on the market to meet domestic food, and energy, needs. In an attempt to become relatively food secure, and thus further water secure (via virtual water trade ${ }^{4}$ ), these countries, such as the Gulf States ${ }^{5}$, looked to purchase foreign lands on which to produce their own goods. With many developing countries subsequently opening their doors to this brand of FDI, large multi-national and transnational companies also jumped on the opportunity to 'grab' cheap and abundant resources.

In application, those occurrences most obviously labelled as land grabs disproportionately affect those living on the edges of society, such as subsistence farmers, minority groups, and indigenous peoples. This is due to the fact that what remains of a country's 'undeveloped' and accessible land and resources will often be located away from urban centres and/or main infrastructure, such as highways. Thus the 'empty' or 'unused' landrhetoric (these designations discussed later in detail), is easily sold to those detached from the realities of the lives of those on the peripheries and from their customary, traditional attachments to the same land constructed as 'available' for investment.

Investors have been sold the idea that the world still holds vast lands that are 'untapped' and 'unused,' 'marginal,' that can be made productive to the benefit of the nation in which they are located and the investing parties. This green Eldorado is a Trojan horse. It has been created so as to dim the realities and make it appear that these large land grabs are indeed no threat whatsoever to food security

\footnotetext{
${ }^{2}$ i.e. the securitization of resources and energy from a state perspective. ${ }^{3}$ Being the side-lined land itself, the environment from an ecological perspective, the resources, the marginalized human stakeholders such as ethnic minorities, etc.

${ }^{4}$ See the work of Tony Allan and Arjen Y. Hoekstra.

${ }^{5}$ For many Middle East Countries the ability to be self-sufficient in terms of food production ended in the 1970s, and thus they became heavily dependent on imports and some of the world's largest virtual water importers per capita.
}

or water security, however at the expense ofpre-existing stakeholders. If the land is vacant then the logic follows, that making it 'productive' is positive development.

A kin to the 'unused' land narrative is the 'inefficient land use' construction. But how do we define an 'efficient' use of land or of water, and for whom? Can it only be defined in commercial terms? The labelling of a land as inefficient implies that it had no purpose in its previous state of use. While a case may be made for industrially degraded lands, the majority of the land-grabbing cases in emerging literature are actually occurring on prime land. This is the case because, in order to develop the land (beyond holding it for speculative purposes), water is required, and as communities and animal life tend to gravitate to freshwater sources, the land is infrequently 'unused'.

The global climate change debate has supported the rise in many alternative, relatively carbon low energy sources. However, the two most important sourcesin terms of the land and water grabissueare biofuels and hydropower.The growth of the biofuel agro-industry has changed the dynamics of land use in producing countries, while a resurge in hydropower development is buoyed by the world's need for 'green energy.'

Many first generation biofuels, such as agrofuels like maize, sugar cane, cassava, are seen as being 'flexi crops,' meaning that their use can be changed dependant on market demands: "soya (feed, food, biodiesel), sugar cane (food, ethanol), oil palm (food, biodiesel,commercial/industrial uses), corn (food, feed, ethanol)" [1]. Yet,when the perceived demands mean that these crops are transformed into fuel, there is considerable distortion of the global food and feed market and the potential for a real increase in food insecurity amongst the global and local population. Another issue with agrofuels, like maize, cassava, sugar cane,etc., is their high water demand. Increasing the use of crops for fuel means that more water resources are being re-directed for their growth, processing and use. According to Philip Woodhouse, "the dimensions of this impact on international agriculture can be gauged from projected increases in land areas dedicated to biofuel production. Estimates of de Fraiture et al. (2008) projected a global total of 42.2 million hectares devoted to biofuels in 2030. White and Dasgupta (2010) cite projections of biofuels accounting for $20 \%$ of global arable land by 2050" [2].Evidently, a re-evaluation of this push for biofuel production in the name of energy security is necessary in order to ensure that certain perceived food insecurities do not become real insecurities.

Policies by global powers like the United States (US) and the European Union (EU) are only exacerbating this issue. The US's American Clean Energy and Security Act and the EU's Renewable Energy Directive 202020 create a market for energy that will reduce their overall emissions and diversify their energy portfolio. However, this comes at the cost of the land and water resources of the producing environment.Although, these policies are likely to hold for some time as the desire to be (green) energy secure remains 
and the push to own the land that can produce this indemand-energy-source will mean more investment and will likely further land grabs ${ }^{6}$. However, it should be remembered that the energy market is always fluctuating. The recent shale gas and 'clean coal' boom in the US and the oil sands of Canada have added another dimension to the fossil fuel versus renewable energy debate in terms of energy security.

\section{Case Study: the Hatgyi}

\subsection{The Salween's River's First Dam}

The Salween River ${ }^{7}$ is oneof mainlandSoutheast Asia's last large undammed rivers. Beginning in Tangula Mountain on the Tibetan plateau, China, (known there as the $\mathrm{Nu}$ Jiang), 4,000m above sea level [4], it flows through Yunnan Province into Myanmar where it forms $120 \mathrm{~km}$ of the border between Myanmar and Thailand before finally emptying into the Gulf of Martaban on the Andaman Sea. While in Myanmar, the Salween River runs through the turbulent ethnic minority territories of Shan, Kayah, Karen (Kayin) and Mon States.

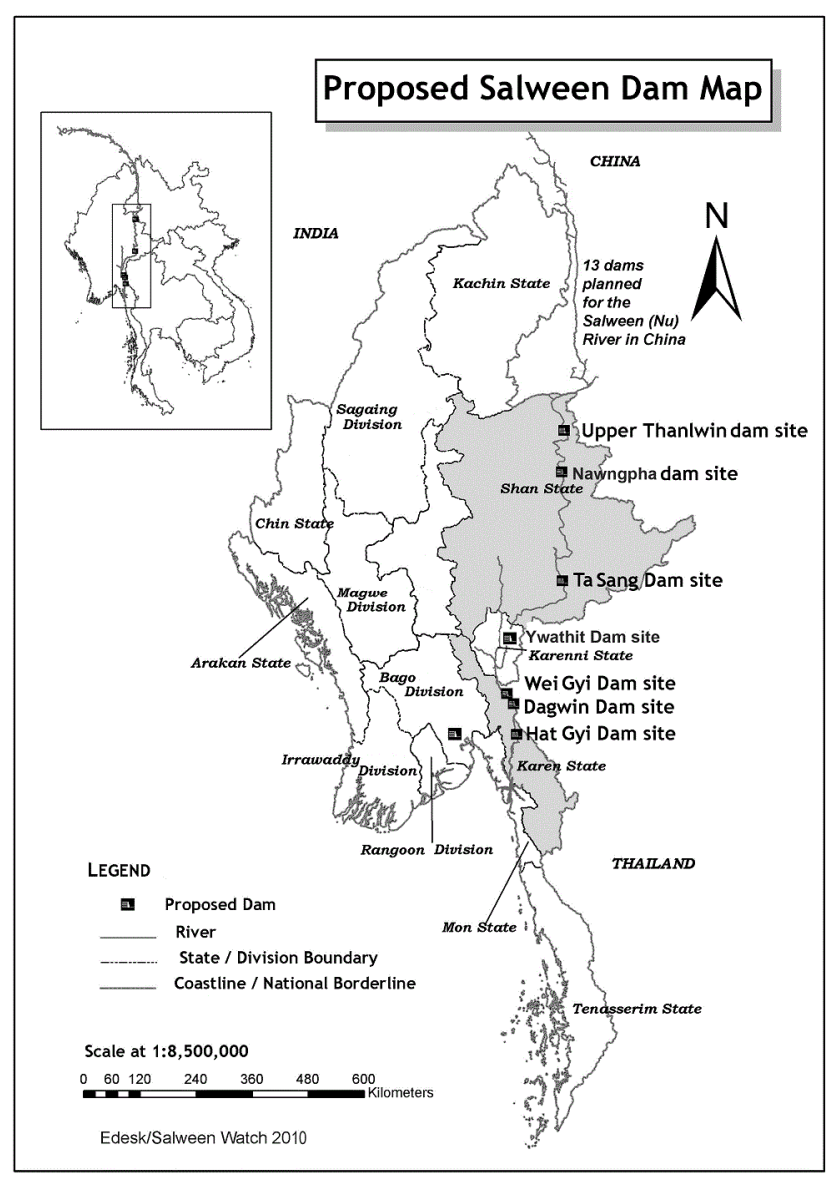

\footnotetext{
${ }^{6}$ However, it should be remembered that the energy market is always fluctuating. The recent shale gas, and 'clean coal,' boom in the US, and the oil sands of Canada, have added another dimension to the fossil fuel vs. renewable debate in terms of energy security.

${ }^{7}$ Known as the Thanlwin in Thailand and the Nujiang in China.
}

Approximately $2,413 \mathrm{~km}$ long, the Salween is,after the Mekong River, the second longest river in Southeast Asia [5]. The river's basin is approximately 271,914 sq.kmstretching over three countries [6]. 53\% is drained in China, $42 \%$ in Myanmar, and 5\% in Thailand [Salween Watch]. The Delta,on the bay of Martaban, is the most denselypopulated section of the basin. It is highly fertile and ideal for wet season rice cultivation. The basin supports over 10 million peopleof more than thirteen different ethnicities [5]. Exploited for irrigation, fishing as well as other traditional activities, the river basinhousesimportant religious sites and cultural capitals.

The government of Myanmar's Hydro Electric Power Department has signed Memorandums of Understandings (MoU) with EGAT (Electricity Generating Authority of Thailand), and various Chinese energy companies, to begin the process of building five to eight ${ }^{8}$ large hydropower dams on the Salween River mainstream. As these MoUs were signed without the consultation of the generalpublic or the consent of the locals in the construction areas, they have become a highly contentiouspolitical subject in Myanmar and Thailand. Inequity, in terms of benefit sharing and compensation, is an immediate follow-on from this lack of involvement. As a representative of the Ethnic Community Development Forum,Sai Khur Seng, so rightly expressed, "energy projects in [Myanmar] should be for the benefit of the Burmese people and not at their expense".

In Myanmar, dammingin general is a sensitive political issue as unilateral development, on the part of the government, has precipitated further armed conflicts in ethnic minority lands. The internationally infamous Myitsone Dam project is only one other example. Positioned on the headway of the Irrawaddy River,this damming project was set to flood an area in Kachin State equivalent to the size of Singapore [7], and lead to the displacement of thousands (estimated 12,000). The project, now suspended,escalated tensions between local armed resistance groups, e.g. the Kachin Independence Army (KIA) and the central government. Similarly, the Salween River dams are mired in the complex, and often violent, civil conflicts of the Eastern border states. Situated in Myanmar's politically constructed 'terra nullius, ${ }^{9}$ these projects risk exacerbating the insecurities of the local population (in terms of safety, livelihoods, water, and food) and jeopardizing fragile ceasefire agreements.

On the upper part of the Salween River/Nu Jiang, China has been planning its own hydropower generating13 dam cascade. If the entire project were to be implemented it would be expected to generate $21.3 \mathrm{GW}$ of electricity (greater than the Three Gorges Dam). However, the project stalled almost ten years ago under Premier Wen Jiabao due to concerns over seismic, environmental and social impacts. However, on January $23^{\text {rd }} 2013$, the government released a notice related to the implementation of the energy portion

\footnotetext{
${ }^{8}$ Several project plans are still at the feasibility study stage.

9'nobody's land' as opposed to terra nulla which is 'no land.'
} 
of its $12^{\text {th }}$ five-year-plan. It was announced in the notice that at least four dams were to be carried out on the upper Nujiang [8]. The dams are to be located in and/or near the Yunnan Three Rivers UNESCO World Heritage Site, raising further controversy. Besides the immediate impacts the dams will have on the local populations(approximately 50,000 people) and the area's biodiversity, the cascade will have far reaching detrimental effects on China's downstream riparians, Myanmar and Thailand ${ }^{10}$.

The planned hydropower projects on the upstream and downstream Salween River threaten delicate ecosystems and the livelihoods ofmillions, the majority of which are from ethnic minority groups. Although the need for lower carbon emitting energy is apparent among the riparian states, these damming projects come at a high price with their benefits being inequitablydistributed among those affected.However, from the government's geopolitical perspective, the Salween River hydropower projects strengthen the Burmese government's position in the region, further establishing itself as a key energy hub. Developing the river as a source of alternative energy aids in Myanmar's regional integrationandbrings the region a step closer towards what Bastien Affeltranger calls the "dream of the ASEAN power grid" [9]. Energysources produced in and exported from Myanmar are already considered as part of the greater Mekong Power Grid, which includes Thailand and China, the region's largest energy consumers. Both countries also purchase electricity from Laos and Vietnam. Thus, the expansion of Myanmar's hydropower export potential would increase its ability to compete with its neighbours as a supplier of 'cheap' energy.

The perceived energy and water security needs of Myanmar's neighbours are what primarily push the hydropower sector to develop the Salween River. The Thai government is heavily dependent $(70 \%)$ on natural gas for its energy production (around 30\% of which it imports from Myanmar)[10]. With an estimated remaining supply of 30years, renewable energy sources such as hydropower are seen asan attractive alternative [10].However, Thailand's growing civil society is staunchly against further hydropower development within their country. Thus, EGAT has been actively promoting hydropower projects in neighbouring states.

EGATis thegenerating body, purchasing company, supplier and distributer of electricityin/to Thailand. It is therefore in their interest to maintain high-energy demandand low-energy costs. Thus, EGAT reputedly forecasts future energy needs well above their actual 'peak load' demands, often with a final discrepancy of as much as $15 \%$ [10]. Considering its powerful standing in Thai national politics and its unrelenting push for hydropower and gas development, land and water grabbing in neighbouring countries with weaker civil societies and

\footnotetext{
10 As flows are altered, sedimentation downstream decreases, eutrophication of slow flow areas occurs (increasing spanning grounds for malaria mosquitoes etc.) and fish migration is interrupted.
}

conservation legislature islikely to continue.

Myanmar, an LDC, sits between India, China and Thailand, three of the regions fastest growing economies (with India and China being in the top four of the world's energy consumers next to Russia and the US). With growing industrialisation, urbanisation, and a burgeoning middle class, their predicted energy needs now and in the future gives rise to immense competition to control regional energy sources. Myanmar, with gas, oil, and hydropower potential, is a country that many have waited for the opportunity to invest in.

Eager to attract foreign investment, Myanmar's reform process has focused heavily on economic reforms, introducing new legislation on foreign direct investment and on Special Economic Zones (SEZs). Under the constitution "the state owns all natural resources" and land [11\&12]. However, environmental regulations and laws are still weak and vulnerable in the face of this fierce development phase. Thus, the first step towards protecting the environment and those who depend on it is to strengthen this branch of law at the national level.With regard to development projects like the Salween River Dams, U Zaw Naing Oo of Resource and Environment Myanmar Ltd (a Burmese consultancy firm)explains that "environmental by-laws have not yet appeared to be able to effectively implement a monitoring plan... if we could have that, it would contain sections such as who should do the monitoring and what kind of groups need to be set up and solve such problems" [13].Until that time, Myanmar's resources, land and water are open to exploitation by unsympathetic investors.Unfortunately, this type of weak environmental regulation is a 'pull' factor for many large extraction and development companies looking to reduce costs by investing in countries where regulations are less demanding in terms of safety and environmental impact regulations.

\section{Method}

According to the Transnational Institute, there are three traditional groups of thought where the issue of land acquisition and resource grabbing is concerned. The first accepts that the process of land acquisition and land use; change needs to happen but should be carried out within a particular legal framework that regulates investment in land. This group focuses their attention onhow to make would-be land grabs into win-win situations for all impacted stakeholders. The second school of thought is resigned to the fact that the grabs are going to continue as a result of the global market system and thus raise the issues of how to mitigate the damage to be caused by such a trend. A land and water rights based approach is favoured as the best way to ensure that any benefits reach those negatively affected by the grabs. The last group sees little, if anything, to be gained by the proliferation of land grabbing and would like to see an end to the expansion and the down-scaling of the grabs that have already occurred. They argue that such 
large-scale and capital-intensive investment is not really necessary for the security of the world in terms of food or climate change. They also argue that, first and foremost, the rights and needs of the pre-existing human and natural stakeholders must be ensured (believing that if this was done, land grabbing would not occur and another solution to these issues would be found). While taking into consideration these various approaches, this paper seeks to objectively project the situation without conforming to any of the three schools of thought. The first step is a thorough understanding of what land and watergrabbing actually means, and to whom, within different contexts [3].

"Water grabbing [is] a situation where powerful actors are able to take control of, or reallocate to their own benefits, water resources already used by local communities or feeding aquatic ecosystems on which their livelihoods are based. This lens demands a focus on how material, discursive, administrative and political power is mobilised to enable such water reallocation and changes to tenure relations as well as the impacts of the latter on local livelihoods, rights, gender, class and other social relations", [1].

The underlying thesis of water grabbing is the same as for land grabbing: control. As a concept, it is concerned with how power is used to achieve that control, usually at the expense of vulnerable primary shareholders (the ecosystem, local peoples, etc). It is impossible not to grab water when grabbing land, and land without an adequate supply of water, for whichever intended purpose, is useless $^{11}$. Water is either essential to facilitate any activity on the land acquired, be it industrial or agricultural, or it is the primary target of a grab, i.e. in the case of hydropower development. Thus, water grabbing is essentially the relocating of domestic, agricultural and industrial water demands to foreign lands perceived to have more abundant water resources. In other words, the investor is buying virtual-water ${ }^{12}$ directly instead of trading for products produced by that country.

Water, unlike land, does not obey boundary lines, and thus the activities of an investor on and around their land will likely have much more far-reaching effects than would be apparent at first. Water can even be considered as 'grabbed,' in a broader sense, if it has been polluted to the point that it is no longer safely/easily used for the purposes it was put to previously. In other words, if a development leads to water being un-potable, or unusable for agriculture and watering of livestock, or even to the build-up of contaminants in an ecosystem, then this water has effectively been 'removed' from the cycle of use in that basin.

The most common type of water grabbing is achieved through a commodification of water, the transfer of 'legal'

\footnotetext{
${ }^{11}$ Except perhaps in some forms of speculation.

${ }^{12}$ Sourced from either green water (of the land) or green \& blue water (from rivers and lakes added to the land). See work of Tony Allan and Arjen Y. Hoekstra for further detail.
}

rights of access, and the privatization of this public good and human right, such that powerful interest groups may redirect/re-distribute it for their own ends. Thus, land grabbing and water grabbing, whether separate goals or overlapping, often occur in countries that have weak legal frameworks, and rights over water and land are unclear. Where there are existing users, there is the problem, as with land rights, of registration which is seen, amongst the commercial market, as the only clear proof of having rights at all. Thus, traditional and communal rights over water and its management are overlooked and unprotected. This can lead to the idea that the water needed by the investor is not in competition with any pre-existing rights holder and that investors are given 'carte blanche' in their utilization of the resources in the purchased/leased area. This myth cannot be sustained, however, in cases where the water/land grabbing is occurring through hydropower development, and most especially in the case of development in an international water basin. The following case study is just such an example. When more than one riparian exists, unilateral or joint development, of the river will have trans-boundary effects, thus the illusion of 'no harm' cannot afford to exist.

\section{The HatGyi ${ }^{13}$ Dam and Water Transfer Project}

The Hatgyi Dam is expected to be the first of the planned Salween River dams to be completed. When built, this gravity dam is expected to stand 33 meterstall with an installed capacity of $1,100-1,500 \mathrm{MW}$, more than triple the initial plans for a 300MW dam outlined by the 1999 feasibility assessment (see Table1) ${ }^{14}$. It is being developed as a joint project between Myanmar Department of Hydro Electric Power, Sinohydro Corp, and EGAT, and will cost over 1 billion USD.However, the Hatgyi Dam site is located in Karen State's Pa-an district, upstream of Pa-an the State capital, and downstream, by 33 kilometres, from the meeting point of the Salween River and its tributary the Moei River [14]. This district, home to the Karen ethnic minority group (among others), is a highly militarized and conflict ridden area of the country. The attempts by the central government to forcefully 'secure' and grab the lands around the projected site has led to much grief amongst the local peoples

\section{Ethnic Issues}

"If they go ahead with the dam. We dare not stay in our village because we are close to the dam site - they'll want us to leave. ${ }^{15}$, The Salween is the main artery that pumps life into the local communities on both banks of the border.

\footnotetext{
${ }^{13}$ Sometimes referred to in literature as: Hatgyi, Hat-gyi, Hutgyi, Hut-gyi, Taung Kyar, Hajji, Hatki.

${ }^{14}$ It should be noted that the site has been moved by around $2 \mathrm{~km}$ from the original site in order to increase the capacity of the dam [Kyaw Thu. Myanmar Times. Issue 334. 18 September 2006].

${ }^{15} \mathrm{Naw}$ Eh Paw a villager who lives along the Salween on the Burmese side.
} 
The villagers rely on it for fish, and the animals and plants that inhabit the rich jungles nourished by the river. The lack of infrastructure in the area, especially all-weather roads, means the Salween is the main means of transport for people needing to get to markets to sell their produce or buy supplies" [15].

Myanmar is home to a plethora of different cultures, languages and ethnic groups. The groups that are most directly affected by the Salween River developments are those located on the edges of Shan, Karen ${ }^{16}$, Kayah, and Mon States (particularly Karen State for the case of the Hatgyi Dam). Of the four, Karen and Kayah State are the most heavily under government military control [16]. The conflict between the KNU (Karen National Union) and the central government is one of the longest civil conflicts in modern history, starting in 1949 after independence, and ending in September 2012 with a ceasefire agreement. At the time of writing this paper this is the longest holding truce between the two sides since the conflict began. Prior to this point in time it had been the express wish of the Burmese Junta (prior to the 2010 elections), along with its allied DKBA (Democratic Karen Buddhist Army) forces, to consolidate its hold of KNU controlled lands along of the Thai-Burmese border by 2010 [17]. This deadline presumably had much to do with the planned Salween River development projects.

The militarisation of the ethnic borderlands, down the length of Myanmar, was seen as key to ensuring that the central government had a strong foothold in the region bordering its strategic trading partners, China and Thailand. Both investing states seek security over their current and future trans-border investment interests (gas, oil, timber, electricity from hydropower, and water transfer). Thus from a Chinese and Thai perspective, border stability is a key driver in encouraging a Burmese development agenda.

The physical nature of the resource being exploited, i.e. a main, trans-boundary river located in contested spaces, means that the area the government is required to 'secure' is spread out and that development of the river for these purposes cannot be done without interfering with the local population's customary uses and rights over that resource. Conversely, 'divide et impera'(to divide and conquer), is evidently one concept behind the recent liberalization and development of the resources in the Eastern border states of the country. Private land concessions in the ethnic Eastern border regions have been given to China, Thailand, private overseas investors, and Burmese interest groups for lumber, mineral extractions, and development projectslike: the Trans Burma-Yunnan pipelines and Salween River hydropower plants. They are scattered around the ceasefire zones of the Shan, Kayah, and Karen States making a spider's web of loosely connected central government control. This power projection in the ceasefire zones can be seen as, "an explicit postwar [sic] military strategy to govern land and populations to produce regulated, legible,

${ }^{16}$ Formerly known as Kayin. militarized territory" [12]. The subsequent strengthening of the central government's suzerainty/sovereignty of the Eastern states is maintained by agreements with local leaders and the presence of policing forces around development sites. Thus, any land concessions given to foreign or domestic bodies leads to the extension of government control over the region in general.

A less obvious result of the water and land grabbing, due to hydropower projects along the Salween River, is the redistribution of the power it causes. Old systems of local authority are altered as new actors develop interests that overlap over the same geographical space. Deals formerly brokered along the Eastern borders between foreign companies and local leaders are now made with the Burmese government, who are now interested in the controlled liberalization of their agriculture and extraction industries, effectively removing local leaders from the negotiations and power play.

\section{The Hatgyi Dam in Detail}

"We don't want any dams in our area," said Saw Kyaw Phoe from Mae Par village in the upper part of the construction site. "If the dam is built, our village -- the whole area -- including our paddy farms and our gardens will be flooded. I, myself, will have no place to live," he said. "We depend on the Salween to irrigate our farms, but the dam will destroy our livelihood," [18].

The life of the project began in 1998 with the start of a pre-feasibility study entitled the "Preliminary Feasibility Study of Hutgyi Hydropower Project in the Union of Myanmar."The studywas carried out with the involvement of Myanmar Electric Power Enterprise (MEPE), the Japanese Marubeni Corporation, the Italian-Thai Development Plc. Co., Ltd., and NEWJEC Inc., the consulting group and subsidiary of Japan's Kansai Electric Power Company [14]. It recommended the construction of a 300MW dam with a small reservoir and minimal flooding at its highest flow to both the Thai and Burmese side of the project. The project is almost entirely foreign-owned. Distribution of the cost for the dam was originally: Thailand 50\%, China 40\%, and Myanmar 10\%.However, China now owns the majority share [19].

\begin{tabular}{|c|c|c|c|c|c|}
\hline \multicolumn{6}{|c|}{ Hatgyi Dam: } \\
\hline Name & Location & $\begin{array}{l}\text { Main Ethnic } \\
\text { Groups Effected }\end{array}$ & $\begin{array}{l}\text { Installed } \\
\text { Capacity }\end{array}$ & $\begin{array}{l}\text { Energy } \\
\text { produced/yr }\end{array}$ & Height \\
\hline Hatgyi & $\begin{array}{l}\text { Thai/Burmese } \\
\text { Border Lands in } \\
\text { Karen State } \\
\text { Pa-an District }\end{array}$ & Karen & $\begin{array}{l}1,100 \mathrm{MW}- \\
1,500 \mathrm{MW}\end{array}$ & $7,335 \mathrm{GhW}$ & $33 \mathrm{~m}$ \\
\hline \multicolumn{6}{|c|}{ Investors: } \\
\hline \multicolumn{6}{|c|}{ Myanmar: Ministry of Electric Power, } \\
\hline \multicolumn{6}{|c|}{ The Intemational Group of Entrepreneurs Co Ltd. (IGE) } \\
\hline Thai: & \multicolumn{5}{|l|}{ EGAT } \\
\hline \multirow[t]{2}{*}{ China: } & \multicolumn{5}{|c|}{ Sinohydro Corporation } \\
\hline & \multicolumn{5}{|c|}{$\begin{array}{l}\text { China Southem Power Grid Co. } \\
\text { China Three Gorges Project Corporation }\end{array}$} \\
\hline
\end{tabular}

Figure2: Specifications of Hatgyi Dam 
Table 1: History of armed resistance in area surrounding dam site.

\begin{tabular}{ll}
\hline $\begin{array}{l}\text { Date: } \\
1949\end{array}$ & Karen Armed Resistance and Hatgyi Dam \\
1994 & Karen National Union (KNU) and the Karen National Liberation Army/ Organization (KNLA/O) its military wing formed. \\
& $\begin{array}{l}\text { The Democratic Karen Buddhist Army (DKBA), a Buddhist soldiers group from within the KNLA sides with the military } \\
\text { junta. }\end{array}$ \\
& KNLA 7th Brigade commander, in charge of Pa-an District, (Hatgyi Dam site), formed the Karen National Union/Karen \\
& National Liberation Army Peace Council (KNU/KNLAPC), a separate group. \\
& KNU/KNLAPC and State Peace and Development Council (SPDC) announce peace agreement \\
2007 February & KNU/KNLAPC, DKBA, and SPDC troops attack KNU near Thai border. \\
2009 June & DKBA and Army start offensive against KNU in Pa-an District \\
2009 July & KNLA Brigade 7 headquarters 'overrun' in Karen State \\
2011 Feb - 2012 Feb & DKBA faction fights with central government over becoming Border Guard Force (BGF) \\
\hline
\end{tabular}

Table 2: Hatgyi Dam Timeline

\begin{tabular}{ll}
\hline & \\
$1998-9$ & Pre-feasibility study \\
2004 & Survey work begins \\
$05 / 2004$ & Two EGAT surveyors killed at site (landmine and grenade fire) - work on hold \\
$12 / 2005$ & MoU signed between EGAT and Myanmar Hydro Electric Power Department \\
$06 / 2006$ & MoU signed between EGAT and Sinohydro on investment in Hatgyi Dam ${ }^{17}$ work starts on power plant and road repair. \\
$02 / 19 / 07$ & EGAT engineer killed in artillery fire - work on Dam on hold \\
$03 / 2008$ & Further MoU with Sinohydro Corp as majority shareholder of Hatgyi Dam \\
$07 / 2009$ & Survey work continued \\
$03 / 2010$ & Joint field survey of Hatgyi Dam site. Burmese, Thai and Chinese engineers \\
$24 / 04 / 12$ & New MoA signed with EGAT, Sinohydro, Myanmar Hydro Electric Power Dept. \& IGE ${ }^{18}$ \\
2012 & Dam and water diversion projects in development \\
\hline
\end{tabular}

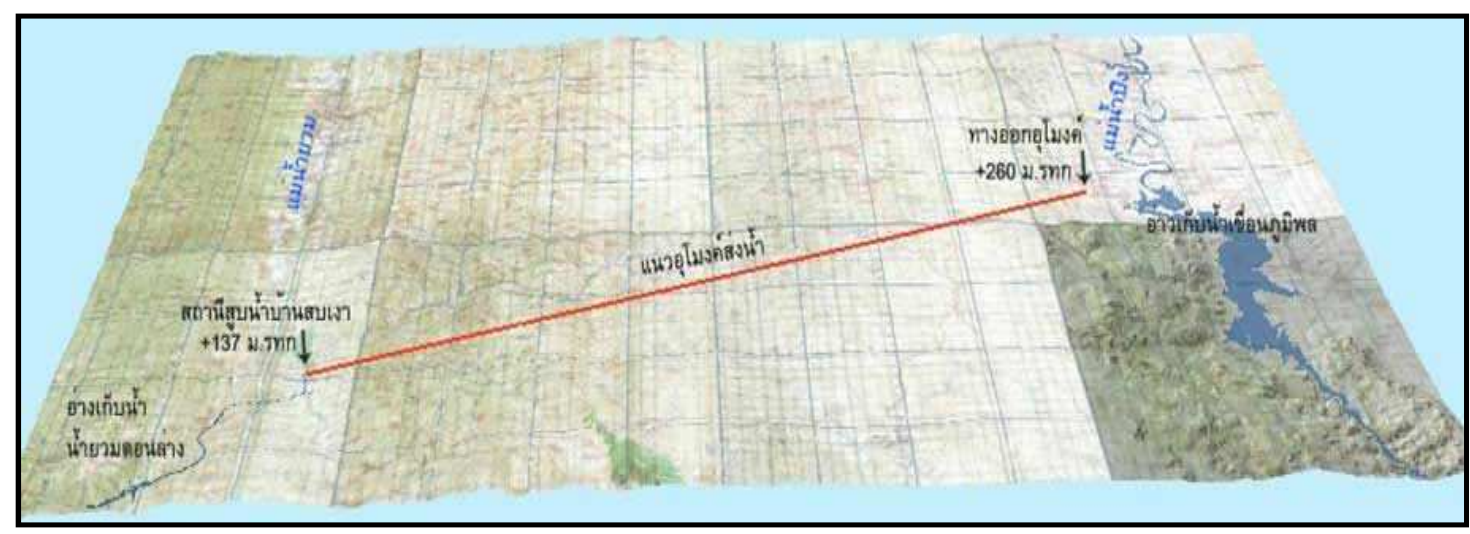

Figure 3: Proposed Pipeline Path

\footnotetext{
${ }^{17}$ According to Pornchai, former chairman of EGAT as well as the former chairman for the subcommittee for negotiating power cooperation with neighbouring States, Sinohydro is the majority shareholder as of March 2008 (responsible for securing the loan for the project), and EGAT second, Burmese government minority shareholder in the project [Shu Huaying, 2008; Watcharapong 2010].

${ }^{18}$ The International Group of Entrepreneurs Co Ltd. of Myanmar.
} 
The agreement to begin work on the dam's development was not concluded until 2009. Previous attempts to move forward with the project were complicated by security concerns, as on at least two occasions EGAT staff were injured and/or killed (see Table 2) because of the conflict that has plagued that part of the country since independence. Indeed, the conflict between several of the ethnic minority groups in Karen State and the central government effects the character of the developments on the river, and vice versa, making the Hatgyi Dam project a very clear and unpleasant example of water/land ${ }^{19}$ grabbing. The projects are moving ahead against the express wishes of the local populations, and violence, an instrumentused by both sides to press their case. However, with the current prospect of a lasting peace in Karen State, as the largest resistance group the KNU (Karen National Union) agrees to a ceasefire, this case study may not end as traumatically as its past trajectory would indicate. With peace talks taking place, and the impacts of the Hatgyi Dam project a part of the negotiations, there is the hope that local concerns may be heard and some rights respected.

Although the Hatgyi Dam is located squarely in Burmese territory and not on the political borderline, the flood zone of the reservoir is set to inundate Thai lands. Additionally, infrastructure required to transfer the energy generated by the dam, and to maintain it, links the project directly to the Thai side, thus creating a wider border area that cuts across Pa-an District.

The Hatgyi Dam's environmental impact assessment (EIA) has been heavily criticized. Due to a former nondisclosure agreement signed between EGAT and the Myanmar Hydro Electric Power Department, Thailand has not made the EIA public (as it is normally obliged to do by law). What has been made available, under considerable pressure, downplays "the environmental and human impacts" and is disparaged "for making dubious claims about the extent of the opposition to the project by the local ethnic Karen" [20]. The reservoir alone will lead to the flooding of Karen State's wildlife reserves. Nongovernmental organizations (NGOs), from both sides of the river, have asked EGAT to carry out a thorough environmental and social impact assessment (EIA/SIA) of the project on the Burmese side, but it has replied that it is unwilling to get involved in what it perceives as a domestic issue (between the Burmese government and citizens).

\section{Inter- Basin Water Transfer}

At the same time as the Hatgyi Dam area was being assessed (February 1998-1999), the feasibility study for the Mae Lama Luang Dam in Thailand on the Yaum River, a Salween River tributary linked to the Moei River, was conducted by Japan's J-Power group [21]. The Mae Lama

\footnotetext{
${ }^{19}$ Here 'water' comes first as the primary objective of the grab and land is second as it is simply the means of securing it.
}

Luang Dam is one the dams that may be built to facilitate the transfer of water from the Salween River Basin to the Bhumipol Dam's reservoir inNorthwest Thailand (one of the country's two largest reservoirs).This bulk water transfer from basin to basin, without consulting, and against desires of,those who are dependent on the river is the most graphic example of water grabbing on this river.

Various routeshave been suggested for the water transfer. Two of theseroutes, the "Salween River-Nam Yuam Upper Dam-Bhumipol Dam's reservoir" and "Salween River-Mae Lama Laung Dam-Bhumipol Dam's reservoir," take water directly from the Salween mainstream by drawing on overflow from the Hatgyi Dam [22].Several other possibilities draw from Salween tributaries. The diverted water will be stored in a second dam, like the Mae Lama Laung (feasibility study done by J-Power February 19981999) or Nam Yuam Upper Dam.From there it is transported through a $60+$ kilometre ${ }^{20}$ pipeline to the reservoir of Bhumipol Dam (refer to Figure3) to be added to reserves stored from the Mekong River basin flows[23]. The project, if completed along these lines, will take seven years.

The transfer of water between basinsis a contentious matter. The exchange deprives the people and the environment downstream of their customary flows.In the case of theSalween River-Mae Lama Laung DamBhumipol Dam's reservoir route, water extraction from the Salween River will only exacerbate the damage caused by the Hatgyi dam itself on the downstream (recall that the Hatgyi is meant to be only the first of the Salween Rivers to be completed). The negative physical effects of the dams and the diversion project: disturbance of sediment flows, loss of aquatic diversity and fish stock, coastal seawater intrusion and salinization of delta soils, etc., put pressure on the livelihoods of those communities dependant on the Salween River basin,and further sour central-periphery political relations in Myanmar.

This development affects two nations across an international borderengendering a different set of governance and accountability issues. The vulnerable stakeholders of the water/land grabbing on the Burmese side may have little or no voice in the matter at present. However, on the Thai side, the level of propaganda and promotion that EGAT has been involved in over the last few years to promote the Salween River dams proves that the voices of the similarly vulnerable Thai stakeholders have an influence over the future of the projects. Thus, the dynamic politics involved across borders does not allow one national narrative to dominate the field. Naypidaw may view the lands around the project as an acceptable loss for the sake of the project, but Thailand may be less quick to bulldoze their own villages. Thus, in this case, the international dimension of the project may be a key factor in mitigating the damage caused by, or in stopping, the project.

\footnotetext{
${ }^{20}$ Taking the lowest estimate.
} 


\section{Concluding Remarks}

A legacy of unsustainable environmental practices has led many of Myanmar's investors to seek water/land grabbing opportunitiesoutside their country. For those States trapped ina situationwith depleted/polluted resources, the options are to rely on the market to provide what they can no longer produce, or 'grab' the resources in a still producing country and be in direct control of supply in order to meet their water/food/energy security needs. Private companies needing to compete on the market are drawn for similar reasons. Land and water grabbing is about control of supply, outside of the restrictions of their country.Thus,Myanmar, with its 'abundant' resources and immature environmental legislature is fertile ground on which to satisfy these geopolitical objectives.

As they revise their investment polices,Naypidaw should demand that investors follow generally accepted principals of social corporate responsibility, such as those laid out by the World Bank. Additionally, the publication of allproject EIAs and SIAs as well as opening the development process to public scrutiny and debate would do much to build confidence.A desire for cheap energy and for quick earnings means that a hydropower project maybe developed solely for the power element and exclude any potential, locally, beneficial by-products, such as irrigation, use of sediments etc. Making the relevant project documents available would mitigate this, and 'unnecessary' projects would be contested from the outset ${ }^{21}$. Currently, damming engineering has advanced to the level where not only has the lifetime of dams been increased, but the options for incorporating related damage mitigation to these inexorable projects is available (sediment rotation, fish passage, etc.). However, many of these measures are impossible to incorporate retroactively, thus the emphasis remains on establishing mechanisms that require that environmental and social needs beprivileged.

Investment agreements, such as those linked to hydropower development or agro-industry,need to outline the rights of the investor in terms of water, taking into account the seasonal and yearly variations in water availability and the needs of those in the same basin, i.e. of the level of stress they place on the basin. This clarification is especially sensitive when investments occur in a transboundary basin.

Unlike many other international rivers, like the Danube and the Mekong, the Salween does not have a commission facilitating information sharing and monitoring of activities and dynamics in the river basin. However, according to Sri $\mathrm{Su}$ Wan, the co-director of TERRA, a Thailand based environmental $\mathrm{NGO}$, there has been a move made to coordinate the creation of a Salween River commission [24]. If such an organization is created, even if only on the Thai side initially (then including Myanmar and China),

\footnotetext{
${ }^{21}$ Myanmar became a full member of ICOLD, the International Commission on Large Dams, in 2011. A positive step, as the country now benefits from knowledge sharing with the other 95 member States.
}

those effected by development projects, on both sides, such as the Hatgyi Dam and water diversion project would have a platform from which to voice their concerns and receive information.Only in an environment of information sharing and consultation can water and land grabbing be prevented.

\section{References}

[1] Mehta, L.; Veldwisch, G.J. and Franco, J..Introduction to the Special Issue: Water grabbing? Focus on the (re)appropriation of finite water resources, Water Alternatives 5(2) (2012) 193-207.

[2] Woodhouse, P, Foreign agricultural land acquisition and the visibility of water resource impacts in Sub-Saharan Africa, Water Alternatives, 5(2) (2012) 208-222.

[3] TNI, Transnational Institute,The Global Land Grab, A Primer, (Oct 2012). http://www.tni.org/sites/www.tni.org/files/download/landgra bbingprimer_0.pdf. 25 January 20133.

[4] Salween Watch, Recent Dams and Water Diversion projects,(2011).http://www.salweenwatch.org/index.php?opt ion=com_content\&view $=$ article \&id= $=51 \&$ Itemid $=60$.

[5] Wolf, T. Aaron, Salween River, In:Managing and Transforming Water Conflicts, Cambridge: Cambridge University Press, (2009), p236-239.

[6] IUCN, IWMI, Ramsar, WRI. Watersheds of Asia and Oceania AS23 Salween, Water Resources Atlas,http://www.burmariversnetwork.org/images/stories/riv ers/eatlassalween.pdf.

[7] Wall Street Journal Staff Reporter, "Tensions Over Dam Projects Shift Myanmar's Politics," The Wall Street Journal, $13^{\text {th }}$ August (2011),http://online.wsj.com/article/SB10001424053111904 006104576504123439749638.html.

[8] Office of the State Council, China. 国务院关于印发能源发 展“十二五”规划的通知/Notice of the State Council on the energy development of the "12th Five-Year Plan. 23 January 2013. http://www.gov.cn/zwgk/201301/23/content_2318554.htm. 1 February 2013

[9] Affeltranger, Bastien. "Inter-basin water transfers as a technico-political option: Thai-Burmese Projects on the Salween River." International Water Security, Domestic Threats and Opportunities. Eds: Pachova, Nakayama, and Jansky. New York/Tokyo: United Nations University, 2008. p 161-179. p163.

[10] Matthews, N. 2012, Water grabbing in the Mekong basin An analysis of the winners and losers of Thailand's hydropower development in Lao PDR, Water Alternatives 5(2) 392-411.

[11] Ei Ei Toe Lwin. Myitsone should not resume, say experts and locals, A Myanmar Times Special Feature, Energy, August (2012), P9. http://www.burmalibrary.org/docs14/Myanmar_Timesenergy2012-red.pdf. [15 October 2012].

[12] Woods, Kevin, Ceasefire capitalism: military-private partnerships, resource concessions and military-state building in the Burma-China borderlands, The Journal of 
Peasant Studies,38:4(2011), 747-770.

[13] Gaung, Juliet Shwe, Concerns remain over Shwe gas benefits, A Myanmar Times Special Feature, Energy, August (2012),p4,http://www.burmalibrary.org/docs14/Myanmar_Ti mes-energy2012-red.pdf. 15 October 2012,[January 2013].

[14] TERRA. Status of The Salween (Thanlwin) Dam Plans. November 1999. http://www.ibiblio.org/obl/docs/SW03.htm 1 Dec 2012.

[15] Burma Rivers Network, Villagers Fear Salween Dam, 8 June (2011),http://www.burmariversnetwork.org/news/11news/578-villagers-fear-salween-dam.html.[ February 2013].

[16] Steinberg, I. David,Burma/Myanmar: What Everyone Needs To Know, Oxford: Oxford University Press, (2010).

[17] Irrawaddy, "KNU to Abandon Bases", 18 June (2009),http://www.irrawaddy.org/article.php?art_id=16078.[ February 2013].

[18] KIC, Karen Information Centre, Hatgyi Dam Generates Problems for Karen Farmers, 1 March (2011).http://www.bnionline.net/feature/kic/10171-hatgyidam-genrates-problems-for-karen-farmers.html.[February 2013].

[19] Burma Rivers Network, Hatgyi Dam,(2013). http://www.burmariversnetwork.org/dam-projects/salweendams/hatgyi.html. [24 September 2012].

[20] International Rivers, The Salween River Basin Fact Sheet, $24 \quad$ May (2012). http://www.internationalrivers.org/resources/the-salweenriver-basin-fact-sheet-7481. [January 2013].

[21] J-Power, Mae Lama Luang, Thailand,http://www.jpower.co.jp/english/international/cons ultation/detail_old/se_as_thailand03.pdf. [1 February 2013].

[22] TERRA, The Salween Water Diversion Project, September (2005).

http://www.terraper.org/mainpage/images/keysub/13057115 62_th.pdf. [February 2013].

[23] DEDE. Conclusion on Project Features of the Water Supplying Lines ofReservoir at Lower Yuam River Reservoir at Bhumibol Dam. http://www.dede.go.th/dede/fileadmin/upload/pdf/Page_9.pd f. February 2013.

[24] Sri Su Wan. Phone Interview. 14 February 2013

[25] Anders, Jägerskog et al. Land Acquisitions: How will they Impact Transboundary Waters? Stockholm International Water Institute, SIWI. 2012

[26] Aung Hla Tun. Myanmar state media details new foreign investment law. Reuters. 3 Nov 2012. http://www.reuters.com/article/2012/11/03/us-myanmarinvestment-idUSBRE8A204F20121103. 6 Nov 2012.

[27] Bangkok Post. Myanmar's investment law: temper applause with caution. 32012 http://www.bangkokpost.com/business/economics/324282/ myanmar-s-investment-law-temper-applause-with-caution. 5 December 2012

[28] Durham University Archaeology Department. How to Build A Dam and Save Cultural Heritage. Workshop. Durham,
July 6th 2012.

[29] Duvail, S.; Médard, C.; Hamerlynck, O. and Nyingi, D.W. 2012. Land and water grabbing in an East African coastal wetland: The case of the Tana delta. Water Alternatives 5(2): 322-343

[30] Earthrights. "Flooding the Future: Hydropower and Cultural Survival in the Salween River Basin." 28 April 2005. http://www.earthrights.org/burma-project/flooding-futurehydropower-and-cultural-survival-salween-river-basin. 15 October 2012.

[31] EGAT, Electricity Generating Authority of Thailand. Main Page. http://www.egat.co.th/ or http://www.egat.co.th/en/. 11 Feb 2013.

[32] ---. Power Development and Future Plan. 2011. http://www.egat.co.th/images/stories/annual/reports/2554/an nual2011_eng_p86.pdf. 11 Feb 2013.

[33] ---. Key Statistical Data, EGAT Annual Report. 2011. http://www.egat.co.th/images/stories/annual/reports/2554/an nual2011_eng_p113.pdf. 11 Feb 2013.

[34] FAO. Foreign direct investment -win-win or land grab?ftp://ftp.fao.org/docrep/fao/meeting/018/k6358e.pdf. Nov 2012.

[35] ---. Salween Dams. 2011 http://www.internationalrivers.org/node/3231. January 2013.

[36] Karen Rivers Watch. Damming at Gunpoint. November 2004.

http://www.freewebs.com/krw_reports/Dam\%20english.pdf. January 2013.

[37] Kay, Sylvia and Franco, Jenny. Transnational Institute. Global Water Grab, A Primer. 13 March 2012. http://www.tni.org/sites/www.tni.org/files/download/watergr abbingprimer-altcover2.pdf. 5 Feb 2013.

[38] Mizzima. Push to build big dams undermines peace process in Karen State. Mizzima News. 14 March 2012. http://www.mizzima.com/news/inside-burma/6758-pushtobuild-big-dams-undermines-peace-process-in-karenstate.html. 1 Feb 2013.

[39] Myint, Soe. The geopolitical challenge for Myanmar's energy sector. A Myanmar Times Special Feature, Energy. August 2012. P2. http://www.burmalibrary.org/docs14/Myanmar_Timesenergy2012-red.pdf. 15 October 2012. January 2013.

[40] Naing, Saw Yan. "KNU Allows EGAT to Survey Salween River Dam." The Irrawaddy. $29^{\text {th }}$ August 2007. http://www.irrawaddy.org/article.php?art_id=84166. $24^{\text {th }}$ October 2012.

[41] Resource and Environment Myanmar Ltd. Projects. 2012. http://www.enviromyanmar.net/projects.html. 12 Feb 2013.

[42] Robinson, Gwen. Myanmar to delay foreign investment law. Financial Times. $17 \quad$ September 2012. http://www.ft.com/intl/cms/s/0/6245e878-00b3-11e2-819700144feabdc0.html\#axzz28DZvsZz4. 3 October 2012.

[43] Salween Watch, The Salween River. http://www.salweenwatch.org/index.php?option=com_conte nt\&view $=$ article \&id=50\&Itemid=59>. 5 February 2013.

[44] ---. Recent Dams and Water Diversion projects. 201). 
http://www.salweenwatch.org/index.php?option=com conte nt\&view $=$ article \&id $=51 \&$ Itemid $=60.5$ February $201 \overline{3}$.

[45] Saw U, Alan. "Reflections on Confidence-building and Cooperation amond Ethnic Groups in Myanmar: A Karen Case Study." P219-235 In: Ganesen, N and Hlaing, Yin Kyaw eds. Myanmar: State, Society and Ethnicity.

[46] Shu Huaying. Sinohydro Corp News Release. 11 March 2008.

http://www.sinohydro.com/english/portlet?pm_pl_id=7\&pm pp_id $=19 \&$ COLUMNID $=11424148920001 \&$ CHCOLUM NID $=11424149100001 \&$ ARTICLEID $=12054551070001$. February 2013.

[47] TERRA, (Towards Ecological Recovery and Regional Alliance). Calling for the Hatgyi Dam to be Stopped Immediately. $\quad 7 \quad$ February 2011 http://www.terraper.org/mainpage/media_detail.php?mid=10 44. 5 January 2013.

[48] Watcharapong Thongrung and Chularat Saengpassa. Controversial Hatgyi Dam to Go Ahead. Nation. 16 February 2010 . http://www.nationmultimedia.com/2010/02/16/business/busi ness_30122674.php. 1 December 2012.

[49] Wolf, T. Aaron. Salween River. p236-239. In Managing and Transforming Water Conflicts. Cambridge: Cambridge University Press, 2009. $\begin{array}{lccc}\text { [50] World } & \text { Bank. } & \text { Thailand. } & 2011 . \\ \text { http://data.worldbank.org/country/thailand. August } 2012 .\end{array}$

[51] U Moe Myint. I expect to see rapid change for the better. A Myanmar Times Special Feature, Energy. August 2012. P6-7. http://www.burmalibrary.org/docs14/Myanmar_Timesenergy2012-red.pdf. 15 October 2012.
[52] UNCITRAL. 1958 - Convention on the Recognition and Enforcement of Foreign Arbitral Awards - Status. 2013. http://www.uncitral.org/uncitral/en/uncitral texts/arbitration /NYConvention_status.html. 11 Feb 2013.

[53] UNCTAD. Investment Policy Framework for Sustainable Development. 12 June 2012. http://www.unctaddocs.org/files/UNCTAD_IPFSD_2012.pdf. 11 October 2012.

[54] ---. World Investment Report 2012 .5 July 2012. http://www.unctad-docs.org/files/UNCTAD-WIR2012-Fullen.pdff. 12 October 2012.

[55] ---. Country fact sheet: Myanmar, World Investment Report $2012 \quad .5 \quad$ July 2012 http://unctad.org/sections/dite_dir/docs/wir12_fs_mm_en.pd f. January 2013.

[56] ---. World Investment Prospects Survey2012-2014. http://unctad.org/en/PublicationsLibrary/webdiaeia2012d21 _en.pdf. 21 October 2012.

[57] UNESCAP. Game-Changing Resolutions for Inclusive \& Sustainable Transformation in Asia and the Pacific Closing Statements. 23 May 2012. http://www.unescap.org/speeches/game-changingresolutions-inclusive-sustainable-transformation-asia-andpacificc. 20 October 2012.

[58] ---. Member States. http://www.unescap.org/about/memberstatess. 20 October 2012. 